\title{
THE INCIDENCE OF PROTEIN SENSITIZATION IN THE NORMAL CHILD *
}

\author{
M. MURRAY PESHKIN, M.D., AND WILLIAM L. ROST, M.D. \\ NEW YORK
}

\begin{abstract}
Although an extensive literature has accumulated on the diagnostic significance of protein sensitization tests in certain disease conditions, no attempt has hitherto been made to examine a large number of normal children for possible potential anaphylactic cases; nor have we been able to find any comparison between the incidence of protein sensitization in a large number of normal and abnormal subjects. The present widespread general interest in protein sensitization, first clinically and conclusively demonstrated by Schloss ${ }^{1}$ and later by the voluminous and epochal researches of Walker, ${ }^{2}$ suggested the necessity of this work.
\end{abstract}

It is the aim of this paper to show:

1. The incidence of protein sensitization in the normal child.

2. The relative frequency of sensitization to the specific protein in relationship to age and diet.

3. The relative frequency of sensitization to horse serum in those who have and those who have not been injected with prophylactic sera of any kind.

The children of this series were mostly Jewish, living on the East Side of Harlem and ranging in age from 2 to 15 years. The sexes were about evenly divided. A consideration of the diet of these children is necessary for a correct interpretation of the various protein reactions recorded. Of the cereal grains, wheat, corn, rice, rye, oats and barley are most common; it is interesting to note that the bread is practically without exception mostly rye. Eggs, milk and cheese are used freely. The meats most frequently eaten are beef and chicken, occasionally lamb and veal and not infrequently goose. Herring, smoked salmon, pike, smelts, and white fish are consumed often and in considerable quantities. Nearly all the different vegetables are used, especially potatoes and peas. As a rule, this class of children does not regularly indulge in vegetables and they are not encouraged to eat them. Fruits are eaten in season. Nuts are eaten occasionally. Milk, coffee and tea are indulged in freely.

Great care was exercised in the selection of the children to be tested. Each child's history was inquired into carefully and a thorough

* Received for publication, Sept. 15, 1921.

* From the Children's Clinic, Mount Sinai Hospital, New York.

1. Schloss, O. M.: Am. J. Dis. Child. 3:341 (April) 1912.

2. Walker, I. C., and Adkinson, J.: J. M. Research 32:287, 1917. 
physical examination made. Only those presenting negative histories and physical evidence of a possible or probable anaphylaxis were tested. The children considered anaphylactic in origin were as follows: Bronchial asthma, recurrent bronchitis, seasonal and perennial hay fever, periodic vomiting, gastro-enteritis, acute and chronic eczema, urticaria, dermatoses, erythema multiforme, angioneurotic edema, iritis and conjunctivitis.

Selection of Protein.-It is extremely important to select the proper material, especially in a series of this character. The protein must be readily soluble and contain all the proteins composing the food. ${ }^{3}$ The activity of most of the proteins was assured by definitely positive reactions in known anaphylactic cases. The protein dilutions were prepared fresh every five days and kept in well corked vials in the icebox. For use the protein was dissolved in tenth normal sodium hydroxid in a strength of $1: 50$.

Technic of the Tests.-The cutaneous scratch test is the one solely employed. After the flexor surface of the forearm has been cleaned with alcohol, linear cuts about $1 / 8$ inch long and $11 / 2$ inches apart are made with a sharp scalpel. The cuts should be deep enough to penetrate the outer layers, without drawing blood. While blood does not interfere with the test, we consider it poor technic and unnecessary. Enough cuts are made at one time for all the proteins to be tested, allowing two for controls. The location of these controls is important; one is near the bend of the elbow where the skin is more sensitive, the second control is placed near the wrist, the tests are made between these two points. On each cut is placed a drop of the test solution. One drop of the tenth normal sodium hydroxid is placed on the controls. After the dissolved protein has remained in contact with the cuts for one half hour, it is wiped away and the reading made. The reactions are always to be compared with the controls. During the test, the proteins must be kept in solution and drying prevented by the addition of a drop tenth normal sodium hydroxid.

If a reaction appears within a few minutes and rapidly becomes larger accompanied by an intense erythema and itching, it is well to wipe away the protein and thus prevent further absorbtion and the disagreeable symptoms of a possible acute anaphylaxis. It must be remembered that even cutaneous tests are not without danger of inducing anaphylactic shock.

Skin Irritability.-If the skin of a patient shows evidence of irritability, this fact should be noted for the proper final interpretation. The less the skin is traumatized, the less the danger of irritation. The

3. All proteins we used were prepared by the methods and under the supervision of R. P. Wodehouse. 
manifestations may be in the form of wheals of different sizes, varying degrees of erythema, or both. These pseudoreactions may appear almost immediately after the cuts are made and be present at the time the true reactions are read. At times cutaneous irritability disappears within from five to ten minutes after the cuts are made, thus not interfering with a proper final reading. At other times it does not begin to appear until from fifteen to twenty minutes after the tests are made. The controls in such cases are very important guides. It is best to make a single row of tests down the forearm about two inches apart and if the tests are repeated, little or no irritability is encountered, enabling us to interpret the end-results more easily and with greater certainty.

Types of Reaction.-Due to a lack of standardization of technic and classification of the reactions, much of the statistical data presented in the literature is more or less confusing, which tends to distract from its value. The technic in our series was carried out by one of us (M. M. P.) thus assuring uniformity of procedure.

The classification we adopted is essentially the one employed by Walker ${ }^{2}$ and is briefly as follows:

1. Positive reaction: (a) Distinct urticarial wheal, $0.5 \mathrm{~cm}$. or more in diameter, surrounded by a zone of erythema in the presence of a negative control. The wheal is always irregular in outline, caused by edema spreading along the lymph spaces.

(b) Distinct urticarial wheal, less than $0.5 \mathrm{~cm}$. in diameter, surrounded by a zone of erythema of two or more $\mathrm{cm}$.

(c) Only a zone of erythema of two or more $\mathrm{cm}$., with little or no elevation about the cut.

2. Doubtful reaction: All reactions measuring less than the above and more than the control.

3. Delayed reaction: This reaction is described by Walker as negative at the end of one half hour, but on the following day the cut appears like a slight infection; the surrounding skin is hot, very red and slightly elevated. Frequently the cut contains pus which is always sterile. This reaction was not noted in our series as the patients were not observed for the twenty-four hours following the tests.

4. Negative reaction: Those not differing in any way from the control.

The Cutaneous Versus the Intracutaneous Reaction.-We have adopted the cutaneous in preference to the intracutaneous test only after very careful and diligent comparisons. The same conclusion was reached by Schloss ${ }^{4}$ who said:

4. Schloss, O. M.: Am. J. Dis. Child. 19:433 (June) 1920. 
During the past few years I have used the cutaneous test entirely as opposed to the intracutaneous test. This was done only after having made a series of tests by both methods on normal patients and on patients suffering from definite food idiosyncrasy. Such tests were made on 100 infants and children not apparently suffering from disturbances due to food, and in thirty who suffered from definite symptoms due to the ingestion of some variety of food. . . The intracutaneous test is more sensitive. In three patients later proved to have mild idiosyncrasy to milk, intracutaneous tests proved positive while cutaneous tests were negative. This seems to be the only point in favor of the intracutaneous test.

Against it is the fact that it is apt to be misleading. Pseudoreactions occur which are difficult to interpret and in some instances patients give reactions which seem positive despite the lack of clinical evidence that the substance tested causes any symptoms. Many vegetable proteins are difficult to obtain in a form soluble in physiologic sodium chlorid solution, but are soluble only in alkaline solvents. Such solutions cannot be used for intradermal tests. To insure sterility, the proteins must be prepared carefully, which adds considerable technical difficulty. On two occasions I have seen severe infections due to such tests. Another objection is that a very sensitive patient may be made seriously ill by the injection of even a minute amount of the protein to which he reacts. In consideration of these objections it seems that, for general use the cutaneous test is the one to be chosen.

Walker ${ }^{2}$ also concludes that:

The skin test is specific; it separates closely related proteins; it is sufficiently sensitive and yet not too sensitive; . . . it is easy to do, and it does not inconvenience the patient. The intradermal test is much less specific; it does not always separate closely related proteins, therefore it may be nonspecific; it is much too sensitive, therefore it is . . . very erratic; it is also more difficult to do, and it causes the patient considerable annoyance and discomfort. Therefore, it is not as practical when many proteins must be tested.

The Cutaneous Reaction in the Normal Child.-Formerly, when a patient with a positive or doubtful reaction developed symptoms resembling any of the now familiar anaphylactic states and the reaction was proved not to be the etiologic factor in the production of the symptoms, the phenomenon was considered an accidental protein sensitization of no significance. It is our belief that, when such reactions occur, these patients are fertile soil and always in danger of developing an anaphylactic condition. We maintain that a normal child exhibiting a skin reaction above the control is a potential anaphylactic case and should be regarded as such.

It must be borne in mind that these children are free from all anaphylactic symptoms because they have acquired a certain amount of individual tolerance against the specific protein causing sensitization. Symptoms develop only when the intake of that protein surpasses the threshold of tolerance. The limit of tolerance varies in different individuals as well as in the same individual at different times. Consequently, it is impossible to predetermine one's tolerance to proteins, or foretell the onset of anaphylactic symptoms by the degree of the skin reaction. A positive reaction does not necessarily predicate the onset of symp- 
toms in one case while a doubtful reaction may augur a very violent attack. Two cases in point are the following:

History.-C. H., male, $5 \frac{1}{2}$ years of age, white, one of a family of eight, one of our series, was last tested in May, 1921. Fifty-two proteins were tested, of which the following showed sensitization: Horse dander, dog hair, cat hair and fig gave positive reactions; egg whole, egg white, cucumber, asparagus, sweet potato, buckwheat, chestnut, chicken feathers and tea gave plus minus reactions. Aug. 16, 1921, he returned to the clinic suffering from a typical attack of bronchial asthma; symptoms much worse at night.

Treatment.-The treatment instituted was a corrective diet, and when he returned two weeks later, he was free from his asthma and as well as ever.

History.-J. T., male, aged 14, white, not in our normal series, has been having attacks of bronchial asthma for the past four years. He was tested against seventy-three proteins consisting of food, serum, epidermal and bacterial. He gave a positive reaction to rabbit hair and a plus minus reaction to horse serum and lamb. These tests were repeated a number of times.

Sept. 16, 1921, he was given a prophylactic dose of 1 c.c. $(1,000$ units) diphtheria antitoxin ${ }^{5}$ and within fifteen minutes he was seized with a severe attack of dyspnea lasting an hour, marked respiratory oppression and profuse expectoration; one-half hour later there developed a generalized erythema and giant urticaria with severe itching, edema of the hands, lips, cheeks and eyelids, marked vertigo, vomiting and cramps. September 17 he was entirely free from asthma, the rash had disappeared, but swellings still were present. $\mathrm{He}$ was tested with horse dander and horse serum which gave very distinct reactions. The reaction to rabbit hair was more intense than ever before. September 19 rabbit hair only gave a positive reaction; horse dander and serum, horse dander alkali metaprotein and orse dander peptone gave negative reactions.

Much of the sensitization occurring in children takes place through the intestinal tract. Talbot ${ }^{6}$ found that "during infancy and childhood practically all cases of sensitization are due to foods." Because of adaptation or desensitization, allergy to food becomes less common as the age of puberty is reached. The author cites literature to show that the gastro-intestinal tract of the newly born infant is permeable to undigested foreign proteins, hence the infant develops the power of destroying such protein up to its limit of tolerance.

In 1913, Richet ${ }^{7}$ stated that "experimental alimentary anaphylaxis is difficult to bring about under conditions of healthy digestion . . . because the individual passes a minimal quantity of unchanged albumin."

Vaughn ${ }^{8}$ asserts that the sensitized group resulting from protein digestion is destroyed in normal digestion; that it is only under abnormal conditions that protein sensitization results through the alimentary tract.

Schloss and Worthen ${ }^{9}$ found that the intestinal tract of normal infants is usually impermeable to undigested foreign protein. In

5. Health Department, New York City.

6. Talbot, F. B.: Boston M. \& S. J. 175:409, 1916; 179:385, 1918.

7. Richet, C.: Seventeenth Internat. Cong. Med., Lond., 1913, Sect. 4, Pt. 1, p. 13.

8. Vaughn: Protein Split Products, 1913. 1916.

9. Schloss, O. M., and Worthen, T. W.: Am. J. Dis. Child. 11:342 (April) 
agreement with other observers quoted by them, they also found that in nutritional or gastro-enteric disorders, foreign protein may be absorbed in an undigested or partially digested state and appear in the urine.

Thus comparing these findings with the evidence presented in Tables 1 to 15 , one can understand how sensitization can readily occur in normal children who occasionally have some gastro-enteric disorder, and who acquire sufficient tolerance to their particular dietary to ward off symptoms of the anaphylactic state.

When that tolerance is exceeded, anaphylactic symptoms become evident. A positive reaction in the normal child may not have the same significance as a doubtful reaction in the abnormal child even though he shows multiple positive reactions.

C. T., a white male child, aged 10, suffering from repeated attacks of bronchial asthma for the past eight years (referred by Dr. Mary Rose) gave positive reactions to buckwheat, wheat glutenin, and globulin, potato, cattle hair and horse serum and doubtful reactions to oats, corn, rice, rye, lima beans, beans and horse dander. After careful study he was permitted to have all food except oatmeal, improvement followed immediately and was very evident two days after change in diet. This case distinctly shows tolerance for the positive-reacting proteins and not the doubtful reacting proteins.

Caulfield ${ }^{10}$ has presented cases which show that it is possible for one to escape the clinical manifestations of anaphylaxis even though sensitized to proteins to which exposure is inevitable.

Table 1.-Cases Tested for Sensitization to Cereal Grains

\begin{tabular}{|c|c|c|c|c|c|c|c|}
\hline \multirow[b]{2}{*}{ Protein } & \multicolumn{4}{|c|}{ Number Tested } & \multicolumn{3}{|c|}{ Percentage } \\
\hline & $\begin{array}{l}2-5 \\
\text { Years }\end{array}$ & $\begin{array}{c}5-10 \\
\text { Years }\end{array}$ & $\begin{array}{l}10-15 \\
\text { Years }\end{array}$ & Total & $\begin{array}{l}\text { Posi- } \\
\text { tive }\end{array}$ & Doubt- & $\begin{array}{c}\text { Nega- } \\
\text { tive }\end{array}$ \\
\hline 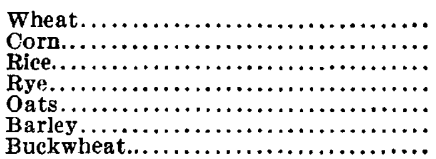 & $\begin{array}{l}24 \\
24 \\
24 \\
24 \\
24 \\
24 \\
11\end{array}$ & $\begin{array}{r}100 \\
100 \\
100 \\
100 \\
100 \\
100 \\
63\end{array}$ & $\begin{array}{l}76 \\
76 \\
76 \\
76 \\
76 \\
76 \\
30\end{array}$ & $\begin{array}{l}200 \\
200 \\
200 \\
200 \\
200 \\
200 \\
104\end{array}$ & $\begin{array}{l}0 \\
0 \\
0 \\
0.5 \\
0 \\
0 \\
0\end{array}$ & $\begin{array}{l}2 \\
0.5 \\
0.5 \\
8.5 \\
1 \\
1.5 \\
1.92\end{array}$ & $\begin{array}{l}98 \\
99.5 \\
99.5 \\
91 \\
99 \\
98.5 \\
98.08\end{array}$ \\
\hline
\end{tabular}

Considering the data presented in the present series, Tables 1 to 8 show the results of the various food proteins tested. In Table 1 the total number of doubtful reactions was thirty among twenty-six children, equally divided as to sex. The one positive reaction to rye occurred in a boy aged 12 years. It is interesting to note seventeen doubtful reactions to rye.

10. Caulfield, A. W.: J. A. M. A. 76:1071 (April 16) 1921. 
The total number of doubtful reactions to egg and milk (Table 2) were eleven occurring in six cases. There were no positive reactions.

TABLE 2.-Cases Tested for Sensitization to Eggs and Milk

\begin{tabular}{|c|c|c|c|c|c|c|c|}
\hline \multirow[b]{2}{*}{ Protein } & \multicolumn{4}{|c|}{ Number Tested } & \multicolumn{3}{|c|}{ Percentage } \\
\hline & $\begin{array}{c}2-5 \\
\text { Years }\end{array}$ & $\begin{array}{c}5 \text {-10 } \\
\text { Years }\end{array}$ & $\begin{array}{l}10-15 \\
\text { Years }\end{array}$ & Total & $\begin{array}{l}\text { Posl- } \\
\text { tive }\end{array}$ & $\begin{array}{l}\text { Doubt- } \\
\text { ful }\end{array}$ & $\begin{array}{c}\text { Nega- } \\
\text { tive }\end{array}$ \\
\hline 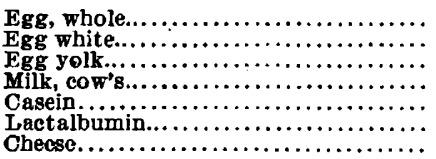 & $\begin{array}{l}19 \\
19 \\
19 \\
19 \\
19 \\
19 \\
12\end{array}$ & $\begin{array}{r}111 \\
111 \\
111 \\
111 \\
111 \\
111 \\
55\end{array}$ & $\begin{array}{l}74 \\
74 \\
74 \\
74 \\
74 \\
74 \\
38\end{array}$ & $\begin{array}{l}204 \\
204 \\
204 \\
204 \\
204 \\
204 \\
105\end{array}$ & $\begin{array}{l}0 \\
0 \\
0 \\
0 \\
0 \\
0 \\
0\end{array}$ & $\begin{array}{l}1.96 \\
1.96 \\
0.98 \\
0 \\
0 \\
0 \\
0.94\end{array}$ & $\begin{array}{l}98.04 \\
98.04 \\
99.02 \\
100 \\
100 \\
100 \\
99.16\end{array}$ \\
\hline
\end{tabular}

When the meat tests were conducted turkey and pork were used as controls, since they are rarely ingested by these children. Four cases showed doubtful reactions, equally divided between beef and veal (Table 3 ).

Table 3.-Cases Tested for Sensitization to Meats

\begin{tabular}{|c|c|c|c|c|c|c|c|}
\hline \multirow[b]{2}{*}{ Protein } & \multicolumn{4}{|c|}{ Number Tested } & \multicolumn{3}{|c|}{ Percentage } \\
\hline & $\begin{array}{l}2-5 \\
\text { Years }\end{array}$ & $\begin{array}{l}\text { 5-10 } \\
\text { Years }\end{array}$ & $\begin{array}{l}10-15 \\
\text { Years }\end{array}$ & Total & $\begin{array}{l}\text { Posi- } \\
\text { tive }\end{array}$ & $\begin{array}{l}\text { Doubt- } \\
\text { ful }\end{array}$ & $\begin{array}{c}\text { Nega- } \\
\text { tive }\end{array}$ \\
\hline 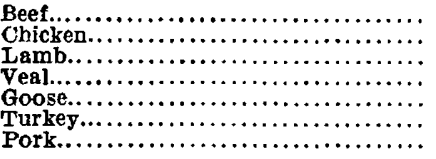 & $\begin{array}{l}13 \\
13 \\
13 \\
13 \\
13 \\
13 \\
13\end{array}$ & $\begin{array}{l}61 \\
61 \\
61 \\
61 \\
61 \\
61 \\
61\end{array}$ & $\begin{array}{l}30 \\
30 \\
30 \\
30 \\
30 \\
30 \\
\mathbf{3 0}\end{array}$ & $\begin{array}{l}104 \\
104 \\
104 \\
104 \\
104 \\
104 \\
104\end{array}$ & $\begin{array}{l}0 \\
0 \\
0 \\
0 \\
0 \\
0 \\
0\end{array}$ & $\begin{array}{l}1.94 \\
0 \\
0 \\
1.94 \\
0 \\
0 \\
0\end{array}$ & $\begin{array}{l}98.06 \\
100 \\
100 \\
98.06 \\
100 \\
100 \\
100\end{array}$ \\
\hline
\end{tabular}

Only one child shows a doubtful reaction to fish (Table 4); the control protein in this series was taken from the oyster.

TABLE 4.-Cases. Tested for Sensitization to Fish

\begin{tabular}{|c|c|c|c|c|c|c|c|}
\hline \multirow[b]{2}{*}{ Protein } & \multicolumn{4}{|c|}{ Number Tested } & \multicolumn{3}{|c|}{ Percentage } \\
\hline & $\begin{array}{c}2-5 \\
\text { Years }\end{array}$ & $\begin{array}{c}5-10 \\
\text { Years }\end{array}$ & $\begin{array}{l}\text { 10-15 } \\
\text { Years }\end{array}$ & Total & Posi- & $\begin{array}{c}\text { Doubt- } \\
\text { full }\end{array}$ & $\begin{array}{c}\text { Nega- } \\
\text { tive }\end{array}$ \\
\hline 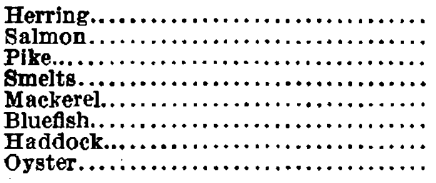 & $\begin{array}{l}12 \\
12 \\
12 \\
12 \\
12 \\
12 \\
12 \\
12\end{array}$ & $\begin{array}{l}55 \\
55 \\
55 \\
55 \\
55 \\
55 \\
55 \\
55\end{array}$ & $\begin{array}{r}\mathbf{3 8} \\
\mathbf{3 8} \\
\mathbf{3 8} \\
\mathbf{3 8} \\
\mathbf{3 8} \\
\mathbf{3 8} \\
\mathbf{3 8} \\
\mathbf{3 8}\end{array}$ & $\begin{array}{l}105 \\
105 \\
105 \\
105 \\
105 \\
105 \\
105 \\
105\end{array}$ & $\begin{array}{l}0 \\
0 \\
0 \\
0 \\
0 \\
0 \\
0 \\
0\end{array}$ & $\begin{array}{l}0 \\
0 \\
0 \\
0.94 \\
0 \\
0 \\
0 \\
0\end{array}$ & $\begin{array}{l}100 \\
100 \\
100 \\
99.06 \\
100 \\
100 \\
100 \\
100\end{array}$ \\
\hline
\end{tabular}


Of nineteen vegetables tested only six gave a doubtful reaction (Table 5). These were asparagus, cucumber, lettuce, peas, white potato and sweet potato; four children showed the reaction.

Table 5.-Cases Tested for Sensitization to Vegetables

\begin{tabular}{|c|c|c|c|c|c|c|c|}
\hline \multirow[b]{2}{*}{ - Protein } & \multicolumn{4}{|c|}{ Number Tested } & \multicolumn{3}{|c|}{ Percentage } \\
\hline & $\begin{array}{c}2-5 \\
\text { Years }\end{array}$ & $\begin{array}{l}\text { 5-10 } \\
\text { Years }\end{array}$ & $\begin{array}{l}10-15 \\
\text { Years }\end{array}$ & Total & $\begin{array}{c}\text { Posl- } \\
\text { tive }\end{array}$ & $\begin{array}{l}\text { Doubt- } \\
\text { fuI }\end{array}$ & $\begin{array}{c}\text { Nega- } \\
\text { tive }\end{array}$ \\
\hline 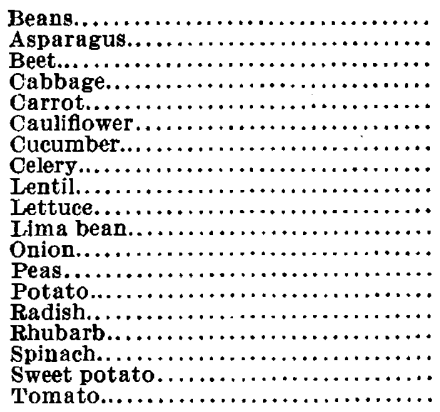 & $\begin{array}{r}11 \\
11 \\
10 \\
11 \\
8 \\
14 \\
14 \\
10 \\
10 \\
10 \\
14 \\
10 \\
11 \\
11 \\
14 \\
10 \\
10 \\
14 \\
10\end{array}$ & $\begin{array}{l}52 \\
63 \\
56 \\
52 \\
60 \\
61 \\
61 \\
56 \\
56 \\
56 \\
61 \\
56 \\
52 \\
52 \\
61 \\
56 \\
56 \\
61 \\
56\end{array}$ & $\begin{array}{l}41 \\
30 \\
40 \\
41 \\
37 \\
32 \\
32 \\
40 \\
40 \\
40 \\
32 \\
40 \\
41 \\
41 \\
32 \\
40 \\
40 \\
32 \\
40\end{array}$ & $\begin{array}{l}104 \\
104 \\
106 \\
104 \\
105 \\
107 \\
107 \\
106 \\
106 \\
106 \\
107 \\
106 \\
104 \\
104 \\
107 \\
106 \\
106 \\
107 \\
106\end{array}$ & $\begin{array}{l}0 \\
0 \\
0 \\
0 \\
0 \\
0 \\
0 \\
0 \\
0 \\
0 \\
0 \\
0 \\
0 \\
0 \\
0 \\
0 \\
0 \\
0 \\
0\end{array}$ & $\begin{array}{l}0 \\
0.96 \\
0 \\
0 \\
0 \\
0 \\
0.93 \\
0 \\
0 \\
0.94 \\
0 \\
0 \\
0.96 \\
0.96 \\
0 \\
0 \\
0 \\
0.93 \\
0\end{array}$ & $\begin{array}{c}100 \\
99.04 \\
100 \\
100 \\
100 \\
100 \\
99.07 \\
100 \\
100 \\
99.06 \\
100 \\
100 \\
99.04 \\
99.04 \\
100 \\
100 \\
100 \\
99.07 \\
100\end{array}$ \\
\hline
\end{tabular}

When fruits were tested, one boy gave a positive reaction to plum, four others gave a doubtful reaction to fig (Table 6).

Table 6.-Cases Tested for Sensitization to Fruits

\begin{tabular}{|c|c|c|c|c|c|c|c|}
\hline \multirow[b]{2}{*}{ Protein } & \multicolumn{4}{|c|}{ Number Tested } & \multicolumn{3}{|c|}{ Percentage } \\
\hline & $\begin{array}{c}2-5 \\
\text { Years }\end{array}$ & $\begin{array}{c}\text { 5-10 } \\
\text { Years }\end{array}$ & $\begin{array}{l}10-15 \\
\text { Years }\end{array}$ & Total & $\begin{array}{l}\text { Posi- } \\
\text { tive }\end{array}$ & $\begin{array}{l}\text { Doubt- } \\
\text { ful }\end{array}$ & $\begin{array}{c}\text { Nega- } \\
\text { tive }\end{array}$ \\
\hline 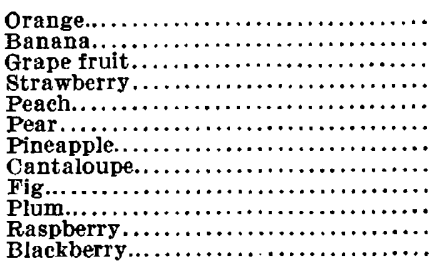 & $\begin{array}{r}8 \\
8 \\
8 \\
8 \\
8 \\
8 \\
8 \\
8 \\
14 \\
14 \\
14 \\
14\end{array}$ & $\begin{array}{l}60 \\
60 \\
60 \\
60 \\
60 \\
60 \\
60 \\
60 \\
61 \\
61 \\
61 \\
61\end{array}$ & $\begin{array}{l}37 \\
37 \\
37 \\
37 \\
37 \\
37 \\
37 \\
37 \\
32 \\
32 \\
32 \\
32\end{array}$ & $\begin{array}{l}105 \\
105 \\
105 \\
105 \\
105 \\
105 \\
105 \\
105 \\
107 \\
107 \\
107 \\
107\end{array}$ & $\begin{array}{l}0 \\
0 \\
0 \\
0 \\
0 \\
0 \\
0 \\
0 \\
0 \\
0.98 \\
0 \\
0\end{array}$ & $\begin{array}{l}0 \\
0 \\
0 \\
0 \\
0 \\
0 \\
0 \\
0 \\
3.73 \\
0 \\
0 \\
0\end{array}$ & $\begin{array}{c}100 \\
100 \\
100 \\
100 \\
100 \\
100 \\
100 \\
109 \\
96.27 \\
99.07 \\
100 \\
100\end{array}$ \\
\hline
\end{tabular}

Only one child gave a doubtful reaction to nuts (Table 7 ). This sensitiveness was shown to chestnut.

TABLE 7.-Cases Tested for Sensitization for Nuts

\begin{tabular}{|c|c|c|c|c|c|c|c|}
\hline \multirow[b]{2}{*}{ Protein } & \multicolumn{4}{|c|}{ Number Tested } & \multicolumn{3}{|c|}{ Percentage } \\
\hline & $\begin{array}{c}2-5 \\
\text { Years }\end{array}$ & $\begin{array}{l}5-10 \\
\text { Years }\end{array}$ & $\begin{array}{l}10-15 \\
\text { Years }\end{array}$ & Total & $\begin{array}{c}\text { Posi- } \\
\text { tive }\end{array}$ & $\begin{array}{l}\text { Doubt- } \\
\text { ful }\end{array}$ & $\begin{array}{c}\text { Nega- } \\
\text { tive }\end{array}$ \\
\hline 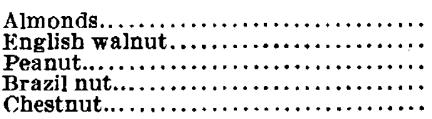 & $\begin{array}{l}11 \\
11 \\
11 \\
11 \\
11\end{array}$ & $\begin{array}{l}52 \\
52 \\
52 \\
52 \\
63\end{array}$ & $\begin{array}{l}41 \\
41 \\
41 \\
41 \\
30\end{array}$ & $\begin{array}{l}104 \\
104 \\
104 \\
104 \\
104\end{array}$ & $\begin{array}{l}0 \\
0 \\
0 \\
0 \\
0\end{array}$ & $\begin{array}{l}0 \\
0 \\
0 \\
0 \\
0.96\end{array}$ & $\begin{array}{l}100 \\
100 \\
100 \\
100 \\
99.04\end{array}$ \\
\hline
\end{tabular}


The common beverages, coffee, tea and cocoa, gave three doubtful reactions; two for coffee and one for tea; one child was sensitive to both (Table 8).

TABle 8.-Cases Tested for Sensitization to Beverages

\begin{tabular}{|c|c|c|c|c|c|c|c|}
\hline \multirow[b]{2}{*}{ Protein } & \multicolumn{4}{|c|}{ Number Tested } & \multicolumn{3}{|c|}{ Percentage } \\
\hline & $\begin{array}{l}2.5 \\
\text { Years }\end{array}$ & $\begin{array}{c}5-10 \\
\text { Years }\end{array}$ & $\begin{array}{l}\text { 10-15 } \\
\text { Years }\end{array}$ & Total & $\begin{array}{c}\text { Posi- } \\
\text { tive }\end{array}$ & $\begin{array}{l}\text { Doubt- } \\
\text { ful }\end{array}$ & $\underset{\text { Nega- }}{\text { tive }}$ \\
\hline 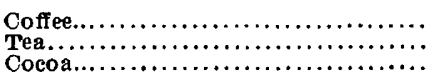 & $\begin{array}{l}11 \\
11 \\
11\end{array}$ & $\begin{array}{l}63 \\
63 \\
63\end{array}$ & $\begin{array}{l}30 \\
30 \\
30\end{array}$ & $\begin{array}{l}104 \\
104 \\
104\end{array}$ & $\begin{array}{l}0 \\
0 \\
0\end{array}$ & $\begin{array}{l}1.92 \\
0.96 \\
0\end{array}$ & $\begin{array}{r}98.08 \\
99.04 \\
100\end{array}$ \\
\hline
\end{tabular}

In Table 9 are presented the results of tests with the proteins from the epidermis of the horse, dog, cat, chicken and goose. The three positive reactions occurred in a boy aged $5 \frac{1}{2}$ years. Six doubtful reactions were observed in six children. The children who showed doubtful reactions to horse dander gave negative reactions to horse serum and had never received injections of any kind of serum.

\section{TABLE 9.-Cases Tested for Sensitization to Epidermal Proteins}

\begin{tabular}{|c|c|c|c|c|c|c|c|}
\hline \multirow[b]{2}{*}{ Protein } & \multicolumn{4}{|c|}{ Number Tasted } & \multicolumn{3}{|c|}{ Percentage } \\
\hline & $\begin{array}{l}2-5 \\
\text { Years }\end{array}$ & $\stackrel{5-10}{\text { Years }}$ & $\begin{array}{l}\text { 10-15 } \\
\text { Years }\end{array}$ & Total & $\begin{array}{c}\text { Posi- } \\
\text { tive }\end{array}$ & $\begin{array}{l}\text { Doubt- } \\
\text { ful }\end{array}$ & $\underset{\text { tive }}{\text { Nega- }}$ \\
\hline 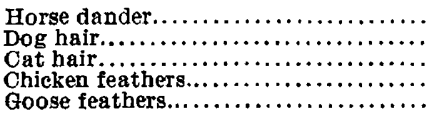 & $\begin{array}{l}19 \\
11 \\
11 \\
11 \\
11\end{array}$ & $\begin{array}{r}111 \\
63 \\
63 \\
63 \\
63\end{array}$ & $\begin{array}{l}74 \\
30 \\
30 \\
30 \\
30\end{array}$ & $\begin{array}{l}204 \\
104 \\
104 \\
104 \\
104\end{array}$ & $\begin{array}{l}0.49 \\
0.96 \\
0.96 \\
0 \\
0\end{array}$ & $\begin{array}{l}1.96 \\
0.96 \\
0 \\
0.96 \\
0\end{array}$ & $\begin{array}{r}97.55 \\
98.08 \\
99.04 \\
99.04 \\
100\end{array}$ \\
\hline
\end{tabular}

The incidence of sensitization to horse serum was determined by a more extensive series of tests to determine the relative safety of administering diphtheria antitoxin. The only child who gave a doubtful reaction to horse serum (Table 10) was a boy, aged $31 / 2$ years, whose history as to diphtheria was negative and who had never received an injection of any kind of serum.

TABLE 10.-Cases Tested for Sensitization for Horse Serum

\begin{tabular}{|c|c|c|c|c|}
\hline Age & $\underset{\text { Cases }}{\text { Number }}$ & $\begin{array}{l}\text { Number } \\
\text { Positive }\end{array}$ & $\begin{array}{l}\text { Number } \\
\text { Doubtful }\end{array}$ & $\begin{array}{l}\text { Number } \\
\text { Negative }\end{array}$ \\
\hline 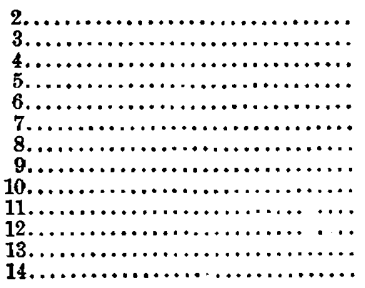 & $\begin{array}{r}3 \\
27 \\
26 \\
50 \\
50 \\
54 \\
56 \\
44 \\
51 \\
50 \\
30 \\
27 \\
9\end{array}$ & $\begin{array}{l}0 \\
0 \\
0 \\
0 \\
0 \\
0 \\
0 \\
0 \\
0 \\
0 \\
0 \\
0 \\
0\end{array}$ & $\begin{array}{l}0 \\
1 \\
0 \\
0 \\
0 \\
0 \\
0 \\
0 \\
0 \\
0 \\
0 \\
0 \\
0\end{array}$ & $\begin{array}{r}3 \\
26 \\
26 \\
50 \\
50 \\
54 \\
56 \\
44 \\
51 \\
50 \\
30 \\
27 \\
9\end{array}$ \\
\hline 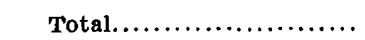 & 477 & $\overline{0}$ & $\overline{1}$ & $\overline{476}$ \\
\hline
\end{tabular}


Table 11 shows the interval between the injection of diphtheria antitoxin and the skin test for horse serum. Eighty children were tested and all reacted negatively. Four were injected twice as they had the disease twice.

TABLE 11.-Interval Between Horse Serum (Diphtheria Antitoxin) Injection and Date When Horse Serum Tests Were Made

\begin{tabular}{|c|c|c|c|}
\hline 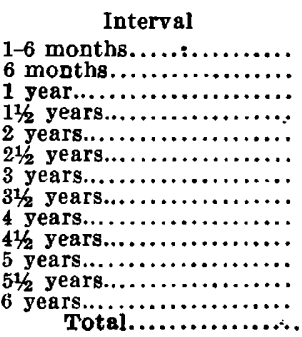 & 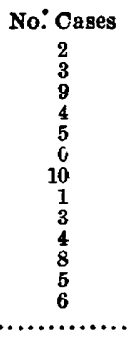 & 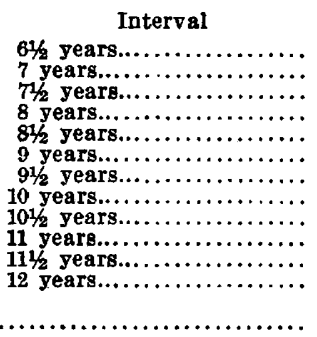 & $\begin{array}{c}\text { No. Cases } \\
2 \\
3 \\
1 \\
5 \\
3 \\
2 \\
1 \\
1 \\
1 \\
2 \\
2 \\
1 \\
84\end{array}$ \\
\hline
\end{tabular}

Table 12 gives the ages of the patients at the time of testing.

Table 12.-Age of Patients at Time of Testing for Horse Serum and Having Had Injections of Diphtheria Antitoxin

\begin{tabular}{|c|c|c|c|}
\hline 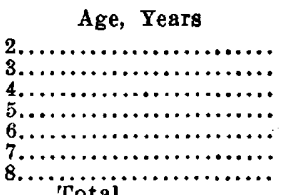 & $\begin{array}{c}\text { No. Cases } \\
0 \\
0 \\
4 \\
3 \\
7 \\
12 \\
13\end{array}$ & 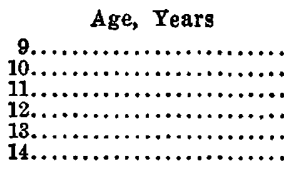 & $\begin{array}{c}\text { No. Cases } \\
10 \\
8 \\
6 \\
8 \\
4 \\
5 \\
80\end{array}$ \\
\hline Total.............. & & $\cdots \ldots \ldots \ldots, \ldots, \cdots$ & 80 \\
\hline
\end{tabular}

All positive reactions of the entire series are summarized in Table 13. There was none among the children aged from 2 to 5 years. Two boys in the five to ten year period gave four positive reactions; one boy in the from ten to fifteen year period was sensitive to rye. Thus in a series of 719 tests, there were five children who gave positive reactions. These occurred in three boys. The boy who was sensitive to horse dander, dog hair and cat hair gave a negative history and reaction to horse serum injection.

TABLE 13.--Summary of the Positive Reactions

\begin{tabular}{|c|c|c|c|c|c|c|c|c|}
\hline & $2-5 Y$ & Years & $5-10 \mathrm{Y}$ & Years & $10-15$ & Years & & \\
\hline Protein & $\begin{array}{c}\text { Number } \\
\text { Tested }\end{array}$ & $\begin{array}{l}\text { Number } \\
\text { Positive }\end{array}$ & $\begin{array}{l}\text { Number } \\
\text { Tested }\end{array}$ & $\begin{array}{l}\text { Number } \\
\text { Positlve }\end{array}$ & $\overbrace{\text { Number }}^{\text {Tested }}$ & $\begin{array}{l}\text { Number } \\
\text { Positive }\end{array}$ & $\begin{array}{l}\text { Total } \\
\text { Number } \\
\text { Tested }\end{array}$ & $\begin{array}{l}\text { Number } \\
\text { Positive }\end{array}$ \\
\hline 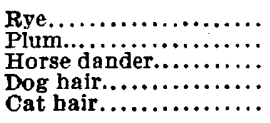 & $\begin{array}{l}24 \\
14 \\
19 \\
11 \\
11\end{array}$ & $\begin{array}{l}0 \\
0 \\
0 \\
0 \\
0\end{array}$ & $\begin{array}{r}100 \\
61 \\
111 \\
63 \\
63\end{array}$ & $\begin{array}{l}0 \\
1 \\
1 \\
1 \\
1\end{array}$ & $\begin{array}{r}76 \\
32 \\
74 \\
30 \\
30\end{array}$ & $\begin{array}{l}1 \\
0 \\
0 \\
0 \\
0\end{array}$ & $\begin{array}{l}200 \\
107 \\
204 \\
104 \\
104\end{array}$ & $\begin{array}{l}1 \\
1 \\
1 \\
1 \\
1\end{array}$ \\
\hline Total............. & 79 & $\overrightarrow{0}$ & $\overline{398}$ & $\overline{4}$ & $\overrightarrow{242}$ & 1 & 719 & 5 \\
\hline
\end{tabular}


In Table 14 we have a summary of the total number of doubtful reactions, sixty-seven in a series of 4,274 tests.

TABle 14.-Summary of the Doubtful Reactions

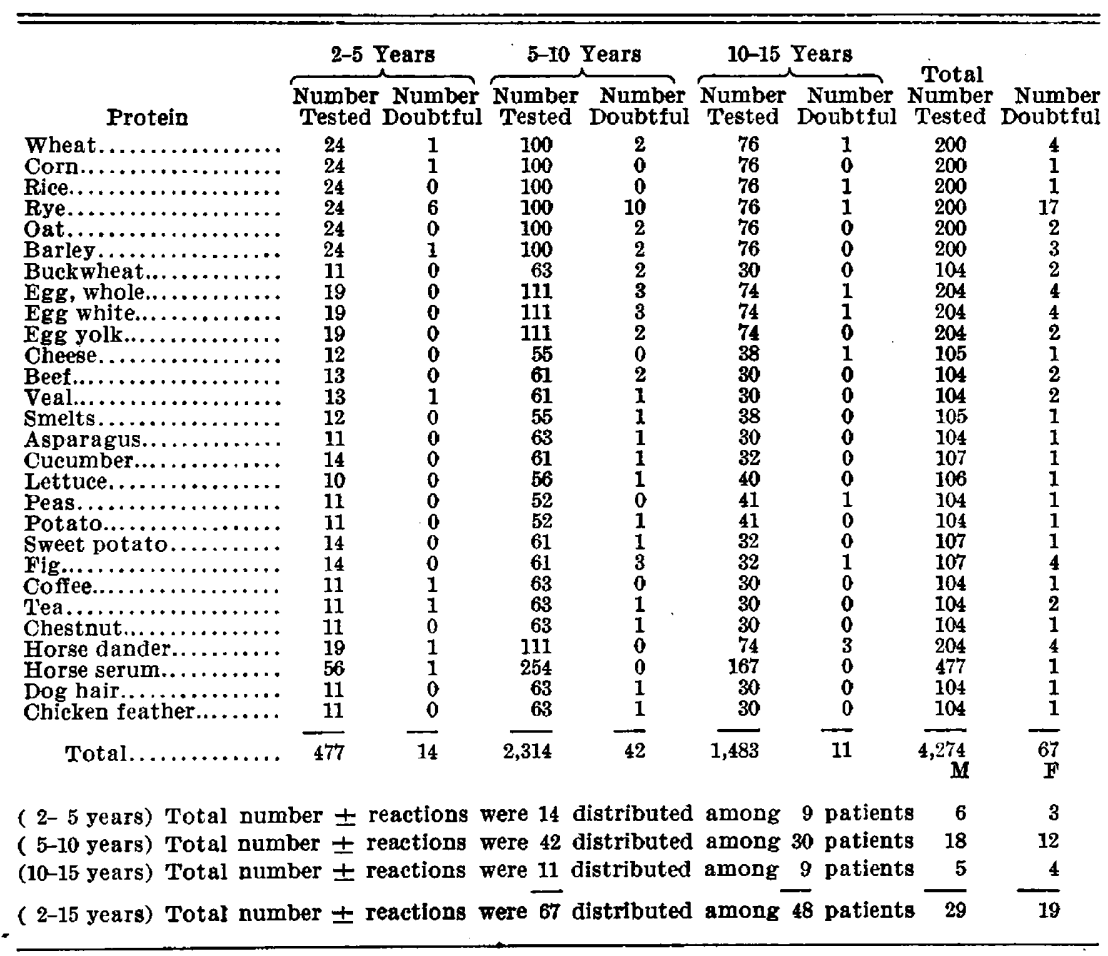

The total number of children tested was 502 . The total number of tests performed was 9,406. Seventy-four different proteins were used in these tests, averaging 18.73 proteins per case. It is interesting to note that rye (bread commonly eaten by these children) gave 3.38 per cent. doubtful reactions of the total actual number of cases tested.

The summary of the entire series is presented in Table 15.

TABLE 15.-Summary of Reactions in Relation to Actual Number of Cases Tested and Tests Performed

\begin{tabular}{|c|c|c|c|c|c|c|c|c|c|c|}
\hline $\begin{array}{l}\text { Age, } \\
\text { Years }\end{array}$ & $\begin{array}{c}\text { Actual } \\
\text { Number } \\
\text { of } \\
\text { Cases } \\
\text { Tested }\end{array}$ & $\begin{array}{c}\text { Number } \\
\text { of } \\
\text { Tests } \\
\text { Per- } \\
\text { formed }\end{array}$ & $\begin{array}{c}\text { Num- } \\
\text { ber of } \\
\text { Posi- } \\
\text { tive } \\
\text { Reac- } \\
\text { tions }\end{array}$ & $\begin{array}{c}\text { Per Cent. } \\
\text { Cases } \\
\text { With } \\
\text { Positive } \\
\text { Reactions }\end{array}$ & $\begin{array}{c}\text { Per Cent. } \\
\text { Positive } \\
\text { Reactions } \\
\text { to No. } \\
\text { of Tests } \\
\text { Performed }\end{array}$ & $\begin{array}{l}\text { Number } \\
\text { of } \\
\text { Doubt- } \\
\text { ful } \\
\text { Reac- } \\
\text { tions }\end{array}$ & $\begin{array}{c}\text { Per Cent } \\
\text { of Cases } \\
\text { With } \\
\text { Doubtful } \\
\text { Reac- } \\
\text { tions }\end{array}$ & $\begin{array}{l}\text { t. Per Cent. } \\
\text { Doubtful } \\
\text { Reactions } \\
\text { to No. } \\
\text { of Tests } \\
\text { Performed }\end{array}$ & $\begin{array}{l}\text { Cases } \\
\text { With } \\
\text { Posi- } \\
\text { tive } \\
\text { Reac- } \\
\text { tions }\end{array}$ & $\begin{array}{c}\text { Cases } \\
\text { With } \\
\text { Doubt- } \\
\text { ful } \\
\text { Reac- } \\
\text { tions }\end{array}$ \\
\hline $\begin{array}{r}2-5 \\
5-10 \\
10-15\end{array}$ & $\begin{array}{rr}5 & 58 \\
0 & 270 \\
5 & 174\end{array}$ & $\begin{array}{l}1,008 \\
5,136 \\
3,262\end{array}$ & $\begin{array}{l}0 \\
4 \\
1\end{array}$ & $\begin{array}{l}0 \\
0.70 \\
0.57\end{array}$ & $\begin{array}{l}0 \\
0.07 \\
0.03\end{array}$ & $\begin{array}{l}14 \\
42 \\
11\end{array}$ & $\begin{array}{l}15.5 \\
11.11 \\
5.17\end{array}$ & $\begin{array}{l}1.38 \\
0.81 \\
0.33\end{array}$ & $\begin{array}{l}0 \\
2 \\
1\end{array}$ & $\begin{array}{r}9 \\
30 \\
9\end{array}$ \\
\hline Total & 502 & 9,406 & 5 & 0.53 & 0.05 & 67 & 9.56 & 0.71 & 3 & 48 \\
\hline
\end{tabular}




\section{CONCLUSIONS}

1. Ten per cent. of the children show doubtful and positive reactions which decrease as their age increases, indicating progressive desensitization. This coincides with Talbot's observations.

2. The incidence of sensitization in normal as compared with abnormal children indicates that the ratios are correct. To compare our incidence of sensitization with a pathologic series, we have found the report of Walker ${ }^{11}$ the most complete. The author tabulates 400 cases of bronchial asthma and makes the following statements; fourfifths of the patients whose asthma began during infancy were sensitive; two-thirds of those whose asthma began during childhood were sensitive; one-half of those whose asthma began during young adult life were sensitive; one-fourth whose asthma began during adult life were sensitive, none were sensitive who began after middle life.

3. The foods giving doubtful and positive reactions are those frequently indulged in and compose an essential part of the dietary of these children.

4. The foods giving the greatest number of reactions in these normal children correspond proportionately with those in the abnormal children.

5. The administration of diphtheria antitoxin incurs practically no risk of anaphylaxis.

6. All reactions above the control are true protein sensitizations and should be regarded as potential anaphylactic cases.

7. It is necessary to institute prophylactic measures in normal cases presenting sensitization without symptoms.

11. Walker, I. C.: A Clinical Study of 400 Patients with Bronchial Asthma, Canad. M. Assn. J. 9:97 (Feb.) 1919. 